\title{
MENGUNGKAP MAKSUD TUTURAN "MEMANG SAYA BELUM DAPAT HIDAYAH" BASUKI TJAHAYA PURNAMA: ANALISIS WACANA PRAGMATIK.
}

\author{
Rohmat*
}

Abstract: The study want to explain the maening of "I have not got bidayab" which is spoken by Basuki Tjahaja Purnama (BTP). For some Muslems these utterence mean positive, therefore, it give simpatic for non_muslem's speaker. To explain othe meaning of a certain utterence need a language analisys callad Discourse Analysis or Pragmatic Language Analisys (PLA). PLA is a study about the use of language which try to elaborate language, spoken or verbally with its contex. The basic concept of PLA as explained by Wijana is Spoken's contex, spoken's act, Implicatu, Principle of teamwork, and unpolitely. Discourse Analisys is comphrenship analisys to understand the spoken's utterence which make some mis understanding. The results shows those utterence is just to guide some opinions of the listeners in order to act casually to Islam. It is not get some simpatic.

Keywords: spoken's act, discourses, hidayah

\section{A. Pendahuluan}

Sebagian besar muslim Indonesia dibuat penasaran oleh pernyataan Basuki Tjahaja Purnama yang akrab dengan panggilan Ahok, khususnya warga DKI yang menganut Islam. Saat menjadi pembicara dalam sebuah

\footnotetext{
*Institut Agama Islam Negeri Tulungagung rahmadinejad16@gmail.com
} 
seminar memperingati maulid Nabi Muhammad SAW., 18 Januari 2015 dengan tema "Rasulullah sebagai pemimpin teladan". Pada acara tersebut Ia berpendapat bahwa seorang pemimpin harus bisa meneladani sifat-sifat yang dimiliki oleh Nabi yaitu, Siddiq, amanah, tabligh dan fathanah. Menurutnya, ia sudah memiliki keempat sifat tersebut hanya saja ia belum dapat hidayah. Ungkapan serupa juga ia sampaikan saat menyerahkan uang sebesar 55 juta kepada BAZIS, pada acara Peduli Umat, Zakat untuk Kesejahteraan Umat' di Plennary Hall JCC, Senayan, Jakarta, Selasa (21/6/2016). Dalam sambutannya, Ahok menyatakan "Saya sejak Bupati (Belitung Timur) saja sudab bayar zakat (sedekah-red), supaya bawahan semua malu. Yang enggak dapat hidayah saja bayar, sedangkan kamu yang mengaku dapat hidayah malah enggak bayar,".

Pernyataan "saya belum dapat hidayah" sepintas menimbulkan beberapa pemahaman: Pertama, Ahok sadar dan mengakui kebenaran ajaran Islam, hanya saja Ia belum diberi hidayah untuk masuk Islam. Kedua, kenyakinan Ahok sekarang ini (non muslim) merupakan kehendak dan takdir dari Allah bukan urusannya.

Maksud suatu ujaran tidak cukup dianalisis dengan mekanisme internak kebahasaan saja, akan tetapi perlu analisis konteks kebahasan secara menyeluruh. Dalam pandangn Cook, untuk mengungkap maksud suatu ungkapan diperlukan pemahaman konteks wacana, seperti latar, situasi, peristiwa dan kondisi. Juga memeriksa kontek sari komunikasi dengan siapa dan mengapa; siapa yang mengkomunikasikan dan siapa yang mendengarkan; dalam jenis khalayak dan situasi apa; melalui medium apa. (Aris Barada 2012: 30)

Ungkapan BJP perlu mendapat perhatian untuk mengetahui makna tutur yang sesungguhnya berdasarkan analisis wacana pragmatis. Data penelitian ini merupakan data kebahasaan dan dilakukan berdasarkan teori kebahasaan pula.

\section{B. Metode}

Istilah wacana yang digunkanan dalam penelitian ini sebagaimana wacana yang ada pada konsep yang dikemukakan oleh Gee dalam (Aris Barada 2012: 186) yaitu menggabungkan unsur-unsur linguistik bersama unsur-unsur nonlinguistik untuk memerankan kegiatan, pandangan, dan 
identitas. Wacana (discourse) dipahami sebagai fenomena kebahasaan utuh dalam komunikasi. Dalam pandangan linguistik, wacana merupakan kesatuan dan keterpaduan makna dalam tiap satuan bahasa yang berkaitan dengan konteks tertentu. Wacana yang dipadukan dengan konteks merupakan hal pembeda dari ketergunaan bahasa dengan tujuan komunikasi dan bahasa yang tidak digunakan sebagai alat komunikasi (Darma, 2014: 2).

Dalam kerangka ini, wacana dipahami sebagai fenomena kebahasaan terlengkap dengan keterlingkupan beberapa unsur kebahasaan: kata, frase, klausa, dan kalimat dalam aktivitas berbahasa. Sebagai titik tekan, analisis wacana berfokus pada penggunaan bahasa dalam konteks sosial atau interaksi antarpenutur (Wijana dan Rohmadi, 2011: 71). Aspek penentu yang sangat signifikan dalam berbahasa dan memahami tuturan adalah konteks.

Pertemuan antara fenomena kebahasaan dengan konsteksnya sebagai bahasa dalam pemakaiannya sesuai dan sejalan dengan kinerja ranah telaah pragmatik, yang merupakan upaya penggabungan antara teks dan konteksuntuk mendapatkan makna suatu ujaran kebahasaan. Dengan demikian analisis wacana merupakan telaah mengenai aneka fungsi (pragmatik) bahasa. Maka analisis wacana tidak dimaksudkan untuk mencari keteraturan dan kaidah tata bahasa, tetapi yang dituntut adalah keteraturan yang berhubungan dengan keberterimaannya pada kahalayak sebagiama diungkapkan (Aris Barada 2012: 187).

Wijana membagi beberapa konsep dasar dalam teori analisis wacana pragmatik menjadi: situasi tutur, tindak tutur, presuposisi, implikatur, prinsip kerja sama, dan kesantunan. Penjelasannya sebagai berikut:

1. Situasi Tutur: Situasi tutur atau suasanatutur bisa merepresentasikan konteks sebagai aspek penting dalam studi pragmatik. Wijana membagi situasi tutur kedalam beberapa komponen: penutur dan lawan tutur, konteks, dan tujuan tuturan. Lebih jauh lagi, Dell Hymes membagi peristiwa tutur dalam delapan komponen yang dikenal dengan SPEAKING: Setting and Scene berkenaan dengan situasi waktu dan tempat terjadinya tuturan, Participants adalah orang yang terlibat dalam tuturan, Ends merujuk pada maksud dan tujuan pertuturan, Act Sequences mengacu pada penggunaan kata atau saluran tutur: lisan atau tulisan, Key seputar nada, cara, dan semangat sebuah 
pesan disampaikan, Instrumentalities penggunaan kaidah berbahasa, Norm mengacu pada aturan interaksi misalnya cara berintrupsi, dan Genres adalah jenis bentuk penyampaian: bentuk narasi, puisi dan doa (Nadar, 2013: 7-8).

2. Tindak Tutur: Langkah awal dalam kajian Pragmatik adalah kajian tindak tutur. Tindak tutur merupakan komponen penting dalam kajian pragmatik, Shahrawi membahasakan tindak tutur sebagai falsafah analisis pragmatik. Falsafah yang dimaksud bukan kajian kebahasaan yang mengungkapkan entitas bahasa dari masa kemasa (perbandingan satu bahasa dalam kurun waktu tertentu), tetapi lebih pada kajian bahasa keseharian. Intisari dalam pemahaman tindak tutur bahwa setiap ujaran terdiri dari bentuk terstruktur, bermakna, dan mengandung sesuatu yang hendak dicapai seperti tuntutan untuk bertindak atau pengaruh. Dalam artian, tindak tutur merupakan penggalian ujaran untuk mengetahui maksud yang ingin dicapai beserta pengaruhnya (Shahrawi, 2005: 17,24). Tindak tutur terbagi dalam tiga macam yaitu tindak tutur lokusi: tindak tutur untuk menyatakan sesuatu, tindak tutur ilokusi: aktivitas bertutur yang mengandung unsur "tuntutan" melakukan sesuatu atau tujuan dan fungsi tertentu, tindak tutur perlokusi: aktivitas bertutur yang disinyalir menumbuhkan pengaruh di benak lawan tutur (Wijana dan Rohmadi, 2011: 21-24). Berdasarkan modusnya, tuturan dapat dibedakan menjadi tuuran langsung dan tuturan tidak langsung. Sedangkan dilihat dari literalnya tuturan dibedakan menjadi tuturan literal yaitu tuturan yang sesuai dengan maksud atau modusnya, dan tuturan yang tidak literal yaitu tuturan yang tidak sesuai dengan tulisan/ujaran.

3. Presuposisi(praanggapan): menduga sebelumnya, berhubungan dengan hal-hal yang diasumsikan oleh penutur sebagai kejadian pratuturan. Sebagaimana diungkapkan oleh (Nababan, 1987:46) praanggapan sebagai dasar atau penyimpulan dasar mengenai konteks dan situasi berbahasa yang membuat bentuk bahasa berupa kalimat atau ungkapan mempunyai makna bagi pendengar atau penerima bahasa dan sebaliknya, membantu pembicara menentukan bentukbentuk bahasa yang dapat dipakainya untuk mengungkapkan makna atau pesan yang dimaksud. 
4. Implikatur(implied meaning): makna tersirat dari sebuah tuturan. Yaitu pesan yang tersirat dalam ungkapan lisan atau wacana tulis. Kata lain implikatur adalah ungkapan secara tidak langsung yakni makna ungkapan yang tercermin dalam kosa kata secara literal (Ihsan, 2011:93). Dengan demikian Implikatur bukan bagian dari tuturan.

5. Prinsip kerja sama: artikulasi tuturan pada sebuah komunikasi dengan tujuan dapat dipahaminya sebuah tuturan oleh lawan bicara. Penyampaian tuturan diusahakan dengan sangat relevan dengan konteksnya, padat, ringkas, mudah dipahami, dan tertuju pada persoalan.

6. Kesantunan: kesantunan memiliki berhubungan dengan dua peserta percakapan: self (penutur) dan other (lawan tutur atau pihak ketiga). Brown-Levinson menganggap kesantunan sebagai motivasi seseorang dalam mempertahankan dan menyelamatkan harga diri yang dimiliki oleh peserta tutur (Black, 2011: 153). Pada istilah lain, kesantunan dapat dipahami sebagai minimalisasi penyerangan harga diri orang lain. Ada beberapa strategi kesantunan yang dibuat oleh BrownLevinson (1987) dalam pertuturan: bald on record (tuturan langsung dan jelas), kesantunan positif (strategi yang digunakan dan berorientasi pada penyelamatan harga diri positif, yaitu keinginan untuk dihargai dan diterima: bersepakat, bekerja sama, memahami dan bersimpati), kesantunan negatif (strategi yang digunakan dan berorientasi pada penyelamatan harga diri negatif yaitu keinginan akan kebebasan dan jauh dari paksaan: menghindari praduga, menolak secara tidak langsung, tidak memaksa, dan meminta maaf), dan off record (membiarkan tuturan ilokusi diinterpretasi dengan sendirinya oleh lawan tutur, apakah tuturan penutur dapat diterima atau diingkari oleh penerima tuturan. Staretgi ini juga membiarkan lawan tutur menyikapi tuturan tersebut, apakah mengancam harga dirinya atau tidak: menyindir, menggunakan kiasan, dan mengulang pembicaraan.

Peneliti akan menggunakan konsep AWP yang telah dipaparkan untuk digunakan menelaah tuturan "Saya belum dapat hidayah", sebagai upaya mengungkap maksud dari tuturan tadi.sedangkan metode yang digunakan dalam penelitian ini adalah metode pragmalinguistik yang dipadukan dengan analisis konten, yaitu gabungan analisis pragmatik 
dengan linguistik struktrural, dengan menyusun interpretasi dari data penelitian (Mulyana, 2005: 7882). Kedua metode ini kemudian dikemas menjadi metode kontekstual, yaitu peneliti berusaha memahami maksud penutur dalam rambu-rambu pragmatik (Kesuma, 2007: 47).

Peneliti melakukan klasifikasi bentuk tuturan berdasarkan tindak bahasa dalam menguak makna atau maksud penutur yang dipadukan dengan konteks dan reaksi lawan tutur. Dengan demikian, frase saya belum dapat hidayah diinterpretasi dan dikontekstualisasi berdasarkan teori yang dipakai guna mengetahui makna tertuntu dalam ujaran BJP tersebut.

\section{Pembahasan}

\section{Peristiwa dan tindak tutur}

Tindak tutur merupakan bagian dari pragmatik. Tindak tutur adalah pengujaran kalimat untuk menyatakan agar suatu maksud dari pembeicaraan diketahui oleh pendengar (Kridalaksana, 1984:154). Tuturan-tuturan dapat dipahami dengan mengaitkan kegiatan yang menjadi konteks dan lokasi tuturan itu terjadi.

Teks muncul didahului oleh suasana atau konteks, karena tuturan muncul ditentukan oleh suana suatu peristiwa. Dari itu penelitian dimulai dengan meneliti konteks "saya belum dapat hidayah" terlebih dahulu yang peneliti formulasikan dalam SPEAKING yang dapat dijabarkan sebagai berikut:

a. Setting.

Tuturan "saya belum dapat hidayah" disampaikan BJP saat menjadi pembicara dalam seminar peringatan Nabi Muhammad $\square$ saw., bertema "Rasulullah Sebagai Pemimpin Teladan", di Gedung Smesco, Ahad 18 Januari 2015. Kegiatan berjalan lancar dan tenang. Kondisi ini mencerminkan bahwa tuturan itu muncul bukan pada saat genting atau tekanan artinya kondisi spikologis penutur dalam kondisi normal. Tuturan ini sengaja diucapkan dan kemungkinan sudah jauh-jauh disiapkan oleh BJP karena sebagaimana kebiasaan bagi seorang pejabat negara tentu undangan untuk manjadi pembicara dalam suatu seminar sudah disiapkan tentang materi yang akan disampaikan. Artinya tuturan ini bukan tuturan dadakan atau karena adanya desakan. 


\section{b. $P$ (articipants)}

Peserta kegiatan seminar adalah orang-orang Islam yang hadir dengan tujuan memperingati Nabi Muhammad SAW. Selain, BJP ada tiga pembicara lainnya, yakni Prof Nasaruddin Umar, Prof Haidar Baqir, dan Prof Abdul Hadi WM.

c. E(ends):

Tuturan "saya belum dapat hidayah" bertujuan menjelaskan kepada pendengar bahwa sebenarnya BJPadalah orang yang paham betul tentang Islam dan sejarah Islam. Sebagai orang yang sempat belajar di sekolah Islam, BJP mengaku sering mempelajari hal-hal tentang Nabi Muhammad SAW. Bahkan dengan lancar Ia menceritakan beberapa kisah tentang Rasulullah. Salah satunya cerita tentang Rasulullah yang dilempari kotoran ketika shalat. Bahkan BJP telah mencotoh sifat-sifat Nabi sebagaimana ungkapannya: "Paling tidak saya sudah punya empat sifat Rasulullah. Tapi saya memang belum dapat hidayah. Karena hidayah itu milik Allah" Tujuan tendensius tuturan ini adalah walaupun BJP paham tentang ajaran Islam dibuktikan dengan pengetahuannya tentang sejarah Nabi yang membawa Islam dan bahkan Ia sendiri dalam keseharian mencontoh sifat-sifat Nabi, namun hal ini tidak serta merta membuatnya memeluk Islam karena menurutnya keimanan (hidayah) seseorang ditentukan oleh Allah. secara tidak langsung ungkapan ini menunjukkan bahwa Allah belum menghendakinya menjadi penganut Islam.

d. A(ct of sequence): saluran tutur yang dipakai adalah lesan tanpa teks tertulis.

e. $K(e y)$ : tuturan diucapkan dengan nada biasa, artinya tidak dengan kemarahan atau nada tinggi, pun juga dengan tidak berbisik-bisik.

f. I(nstrumentalities): tuturan ini menggunakan bahasa indonesia yang baku.

g. N(orms): penutur menjawab pertanyaan lawan tuturnya. Tuturan ini terjadi satu arah artinya tuturan ini tidak berupa tanya jawab. Karena berupa seminar semacam ceramah.

h. G(enre): tuturan ini merupakan kategori tuturan serius ilmiah.

Kemudian, tuturan "saya belum dapat hidayah"jika diklasifikasi berdasarkan tindak bahasanya tergolong dalam tindak tutur ketiga, perlokusi. Tuturan tersebut mencoba untuk memberikan pengaruh 
kepada lawan tuturnya: Penutur ingin memberikan kesan bahwa tuturannya itu benar sesuai norma-norma dan sesuai dalil agama Islam.

Merujuk pada pembahasan diatas, tindak tutur "saya memang belum dapat hidayah" bertujuan memberikan pemahaman kepada pendengar bahwa faktor ke(tidak)Islaman penutur bukan karena penutur tidak tahu tentang Islam, akan tetapi karena penutur tidak mendapatkan hidayah atau dengan kata lain Tuhan belum menghendaki penutur untuk menjadi Muslim. Lebih lanjut tuturan ini "saya memang belum dapat hidayah" dituturkan dihadapan peserta seminar peringatan maulid Nabi Muhammad SAW., yang kesemuanyaberagama Islam mengandung maksud berusaha memberikan pengaruh kepada pendengar untuk bersimpati kepada penutur. Berbeda jika tuturan ini dituturkan dihadapan orang-orang kristiani, yaitu mereka yang tidak menyakini kenabian Muhammad SAW., tentu akan menampakkan maksud dan tujuan berbeda.

\section{Presuposisi dan Implikatur}

Presuposisi berkaitan dengan anggapan dasar dalam konteks tuturan (Mulyana, 2005: 14). Berbahasa mempunyai tujuan untuk mengekprikan gagasan atau pengetahuan kepada orang lain. Presuposisi merupakan anggapan awal bahwa sebelum melakukan tururan sipenutur berasumsi lawan tuturnya akan memahami tuturannya. Namun, dalam hal tertentu peserta tutur terkadang tidak memahami isi dari tuturan. Hal ini dapat dipengaruhi oleh faktor pengetahun dan pengalaman peserta tutur. Faktor pengetahuan dan pengalaman peserta tutur inilah yang kemudian disebut dengan presuposisi (Darma, 2014: 77). Minimnya pemahaman penutur tentang sesuatu hal yang Ia sampaikan akan memunculkan tuturan yang berbeda dengan maksud yang diinginkan.

BJPdiminta oleh panitia untuk menjadi narasumber dalam seminar yang bertemakan "Rasulullah pemimpin teladan". Dalam paparannya ia menjelaskan empat sifat yang dimiliki Nabi Muhammad yakni, Shiddiq (benar), amanah (dipercaya), fathonah (cerdas), dan tabligh (menyampaikan), harus dimiliki setiap pemimpin. Kemudian dia mengatakan "Paling tidak saya sudah punya empat sifat Rasulullah. Tapi saya memang belum dapat hidayah. Karena hidayah itu milik Allah." Tuturan 
saya memang belum dapat hidayah dipengaruhi oleh sosok penutur yang merupakan non muslim yang sedang berbicara dihadapan orang-orang Islam. Frase "saya memang belum dapat bidayah" merupakan frase yang paling dekat dan paling representatif dengan kondisi diri penutur. Dengan ini menunjukkan bahwa fenomena pemahaman pertuturan tidak bisa lepas dari asumsi dasar dan hal tertentu yang dimiliki penutur.

Menurut (Yule, 2006:45) ciri mendasar dari adanya presuposisi adalah sifat keajegan dibawah penyangkalan. Artinya presuposisi suatu tuturan akan tetap ajeg (tetap benar) walaupun tuturan itu dinegasikan atau disangkal. Adapun gambarannya sebagi berikut, tuturan:

(a): "saya belum dapat hidayah".

(b): "saya sudah dapat hidayah".

Tuturan (b) adalah negasi dari tuturan (a). Presuposisi dari tuturan (a) adalah: "saya bukan orang Islam/saya no-muslim", sedangkan tuturan (b) jika dipresuposisi akan menjadi: "saya orang Islam".

Berbeda dengan contoh ungakpan berikut:

(a) "Sepeda motor Wawan bagus"

(b) "Sepeda motor Wawan tidak bagus"

Kalimat (b) merupakan bentuk negasi/penyangkalan dari kalimat (a). Jika diambilkan presuposisi dari kalimat (b) dan kalimat (b) maka kedua kalimat tersebut memiliki presuposisi yang sama (ajeg) yaitu "Wawan memiliki sepeda motor". Inilah ciri-ciri dasar presuposisi yaitu keajegan praanggapan.

Sehingga jika mengacu pada pendapat Yule tersebut tuturan BJP tersebut tidak memiliki presuposisi karena tidak memiliki keajegan ketika dinegasikan.

Dalam analisis wacana kebahasaan, Implikatur merupakan faktor dominan dalam memahami suatu ujaran. Implikatur, yang dipahami sebagai penyiratan dalam tuturan, dilakukan sebagai upaya integratif antara apa yang disampaikan dengan yang dimaksudkan (Mulyana, 2005: 11). Pada tuturan "saya memang belum dapat hidayah. Karena bidayah itu milik Allab", penutur tidak secara langsung menyatakan bahwa saya belum Islam (mendapat hidayah) disebabkan karena Islam adalah pemberian (hidayah milik Allah). Kalau seseorang tidak beriman (tidak menjadi Muslim) bukan salahnya tapi itu kehendak Allah, implikatur seperti ini keliru tapi ujarannya tidak salah. 
Acuan lain dari tuturan "saya memang belum dapat hidayah. Karena bidayah itu milik Allab" penutur ingin memberitahukan bahwa dia belum menjadi Muslim karena belum diberi hidayah oleh Allah. yang menjadi permasalahan sudah atau belumnya dia mendapat hidayah akan tetapi maksud sebenarnya ujaran itu adalah bahwa iman atau tidak imannya seseorang kepada Islam yang menentukan adalah Allah SWT. Dan inilah yang berusaha dipahamkan oleh penutur kepada lawan tutur.

\section{Prinsip Kerjasama dan Kesantunan}

Suasana yang terjadi pada saat tuturan "saya memang belum dapat bidayah", adalah suasana nyaman dan tenang dengan pembahaasn halhal yang bertema keagaman terutama tentang sejarah Nabi Muhammad SAW. Pemateri menyampaikan materinya dengan nyaman dan pendengar mendengarkan dengan hikmad dengan sesekali disertai tertawa ketika narasumbermenyampaikan materinya dengan humor.

Dengan demikian tidak ditemukan pelanggaran kerjasama. Namun, pada faktanyamayoritaskeyakinan yang berkembang dalam Islam,khususnya Islam di Indonesia yang mayoritasnya berpaham Islam Sunni punya kenyakinan bahwa hidayah merupakan sesuatu yang harus dicari dan diusahakan.Karena hidayah termasuk dalam takdir muallaq yaitu takdir yang berhubungan dengan ihktiyar manusia. Sedangkan ungkapan BJP tersebut mnejurus pada pemahaman Jabariah. Jabariah diambil dari kata jabara, berarti memaksa atau terpaksa. Al-Jabr berarti meniadakan perbuatan manusia dalam arti yang sesungguhnya (nafy alfi'il 'al al'abd haqiqah) dan menyandarkan perbuatan itu kepada Tuhan (al-Syahrastani: 115). Paham ini memiliki keyakinan bahwa perbuatan manusia seluruhnya dikendalikan oleh Tuhan, dan manusia tidak memiliki kuasa atas perbuatannya. Adapun pemikiran yang terdapat paham ini bahwa manusia mengerjakan perbuatannya dalam keadaan terpaksa. Dalam istilah inggris, paham ini disebut fatalisme atau predestination. Perbuatan-perbuatan manusia telah ditentukan sejak semula oleh qadha dan qadar Tuhan (Harun Nasution, 1972:31). Jika hidayah itu murni pemberian Allah, tentu mereka yang mati dalam keadaan belum beriman yang kelak disiksa di neraka akan menggugat kepada Allah dengan perkataan: "ya Allah mengapa saya dulu ketika di dunia tidak engkau 
beri hidayah sehingga kami menjadi orang-orang yang inkar kepadamu”. Bukankah sudah datang kepada mereka petunjuk Allah melaluai para utusan-Nya.

Dengan demikian, prinsip ini menghimbau penutur untuk tidak mengatakan sesuatu yang diyakini salah atau nafinya bukti yang memadai (Yule, 2014: 64).

\section{Kesimpulan}

Rangkain garis besar penjabaran analisis tersebut merupakan upaya penulis untuk mengungkap makna dari tuturan "memang saya belum mendapat hidayah". Ungkapan verbal yang dilakukan oleh Basuki Tjahaya Purnama ini oleh penulis dikaji dengan analisis kebahasaan: analisa wacana pragmatik. Adapun simpulan yang diperoleh penulis: Meskipun tuturan "memang saya belum mendapat hidayah" merupakan tuturan yang santun dan kelihatannya masuk, namun tuturan tersebut bertendensi pada:

Pertama, berdasarkan prinsip presuposisi dan implikatur tuturan BJP tersebut tidak memiliki keajegan presuposisi dan memiliki implikatur yang keliru karena rangkaian tuturan yang lugas yang disampaikan penutur merupakan upaya menggiring opini pendengar supaya bersikap wajar terhadap ke(tidak)imanan penutur terhadap Islam bahkan sampai pada maksud untuk mencari simpati.

Kedua, tuturan ini telah melanggar prinsip kerjasama dan kesantunan dengan mempertimbangkan fakta ajaran yang diyakini oleh mayoritas umat Islam. Dengan menuturkan "memang saya belum mendapat hidayah, karena hidayah itu milik Allah" secara tidak langsung tuturan ini mengandung maksud bahwa iman dan tidak imannya seseorang itu merupakan ketentuan langsung dariAllah, manusia tidak bisa mengusahakan. Keyakinan seperti ini bertentangan dengan keyakinan mayoritas lawan tutur yang menyakini bahwa dalam urusan takdir, manusia memiliki andil dalam menentukan takdir hidupnya. 


\section{Daftar Pustaka}

Al-Syahrastani. (t.t) Al-Milal Wa Al-Nihal. Beirut: Dar al Fikr.

Black, Elizabeth. (2011). Stilistika Pragmatis. terj. Ardiyanto, dkk. Yogyakarta: Pustaka Pelajar.

Darma, Yoce Aliah. (2014). Analisis Wacana Kritis, Bandung: Refika Aditama.

Harun Nasution. (1972) Teologi Islam: Aliran, Sejarah Analisa Perbandingan, Jakarta: UI Press.

Ihsan, Dimroh. (2001) Pragmatik Analisis Wacana, dan Guru Bahasa. Palembang. Universitas Sriwijaya.

Kridalaksana. Hari Murti. (1982) Kamus Linguistik. Jakarta. PT Gramedia.

Kesuma, Tri mastoyo Jati, (2007). Pengantar (Metode) Penelitian Bahasa, Yogyakarta: Carasvatibooks.

Mulyana, Kajian Wacana. (2005). Yogyakarta: Tiara Wacana.

Nababan, P.W.J. (1984) Sosiolinguistik Suatu Pengantar. Jakarta. PT Remaja Rosdakarya.

Nadar F.X., (2013).Pragmatik E Penelitian Pragmatik. Yogyakarta: Graha Ilmu.

Shahrawi, Mas'ud. (2005).At-Tadawuliyah 'Indal 'Ulama'il 'Arab. Beirut: Darut Tali'ah.

Wijana, I Dewa Putu dan Muhammad Rohmadi, Analisis Wacana Pragmatik: Kajian Teori dan Analisis, Surakarta: Yuma Pustaka.

Yule, George. 2014. Pragmatik, terj. Indah Fajar Wahyuni, Yogyakarta: Pustaka Pelajar. 